\title{
Transitions to Entrepreneurship
}

\section{Robert P McGowan*}

Department of Management, Daniels College of Business, University of Denver, Colorado, USA

The creation of new organizations is among the most important forces of social and economic development. New organizations promote growth and development, advance new technologies, redefine products and processes and, in some cases, create entirely new industries. Witness the success of such firms as Facebook, Google, Amazon and others. While most would agree on the importance of new organizations, there is little agreement about how or whether we can predict their birth. Most organizations undergo a life cycle-not dissimilar to product life cycles [1].

In the initial stage of the enterprise-the most entrepreneurial-the founder or idea generator has limited resources or sources of funding. Yet he/she tends to take the most risks and feels very passionate about the product or service. The organizational structure is typically loose and informal. Indeed there is little need for a hierarchical structure, which can stifle growth. The best example of this growth pattern is Intel Corporation which had split off from Fairchield Semiconductor in the San Francisco Bay area. Gordon Moore and Robert Noyce wanted to avoid the trappings of a larger enterprise and introduced an open-door policy, the use of cubicles-not corner offices-and the individuals most rewarded came from the front line associates. Yet, out of necessity, the organization transitions to the second phase of development-the early growth phase. Cash flow and providing a positive return is now paramount and the entrepreneur will need to build a management team around himself or herself. The simple reason is that the entrepreneur is still passionate about the endeavor but must introduce some systems and controls. This does not need to be onerous but maintaining costs is the key. In addition, the entrepreneur needs to surround himself or herself with the key skill set for growth-whether it is cost accounting, inventory management, sales forces development, etc. Failure to do so is a recipe for disaster since the entrepreneur can only devote so much time to the firm and must decide what the key is. Indeed, if one looks at successful organizations today, the leader or figurehead receives all of the attention but it is the team that they have built around them which is the key to their success. As for the third phase of growth, sustained growth, the organization needs to become more formalized. The entrepreneur is looking at possible capital for scaling the business. This would rate an entire new discussion but ranges from "bootstrapping" (i.e., doing it on your own), angel investors (i.e., high net worth individuals) or venture capital (i.e., private equity). Each source has its own risks and rewards but the entrepreneur needs to determine the appropriate balance. In addition, the entrepreneur usually transitions from the organization at this stage-whether as part of an agreement from a firm that is acquiring them or by their own design. In certain cases, you will find "serial entrepreneurs"- those that start one firm and then move on to another. For them, it is more of a passion to see that it can be done, rather than an exact science. Finally, there is the mature phase of the business. The firm has successfully passed through all the prior stages. The challenge now is how to sustain and maintain growth. In addition, these organizations need to continue to innovate. There are many companies that have been excellent at this-Apple, $3 \mathrm{M}$, Haier, Wal-Mart, Nike, and GE. To maintain the competitive spirit, they are engaging in new forms of cooperation, ranging from strategic alliances and joint ventures, outsourcing, supply chain logistics. The key is flexibility and maintaining their core competencies. In sum, organizations face a variety of challenges as the mature and grow. The key is to engage in entrepreneurial activities at each phase and build a solid team of individuals who can complement one another.

\section{Reference}

1. Greiner LE (1972) Evolution and Revolution as Organizations Grow. Harvard Business Review 50: 37-46.
*Corresponding author: Robert P McGowan, Department of Management, Daniels College of Business, University of Denver, Colorado, USA, E-mail: rmcgowan@du.edu

Received November 08, 2012; Accepted November 09, 2012; Published November 14, 2012

Citation: McGowan RP (2012) Transitions to Entrepreneurship. J Entrepren Organiz Manag 1:e105. doi:10.4172/2169-026X.1000e105

Copyright: ( 2012 McGowan RP. This is an open-access article distributed unde the terms of the Creative Commons Attribution License, which permits unrestricted use, distribution, and reproduction in any medium, provided the original author and source are credited. 